\title{
PARANOIA AND ITS ENSUING EFFECTS IN KEN KESEY'S ONE FLEW OVER THE CUCKOO'S NEST
}

\author{
Nasser Maleki \\ Razi University, Kermanshsh, Iran \\ Hassan Abootalebi \\ Lorestan University
}

\begin{abstract}
The present paper examines the applicability of paranoia and its ensuing effects on individuals in Ken Kesey's One Flew over the Cuckoo's Nest (1962). It is significant to analyze and discuss how authorities in a given culture impose controls on mavericks so as to forestall possible threats. Paranoia in the above-mentioned work, it is argued, engenders a perennial phobia on sufferers which brings about an identity crisis exerting influence over the temperament and conduct of them. Kesey's work indeed perfectly exemplifies the sort of treatment undergone by those suffering from mental illness and the way they are mistreated. McMurphy, the protagonist, being cognizant of the way authorities codify stringent regulations on their subjects seeks to exhort those confined in the hospital to extricate themselves from their pathetic and deplorable condition and to disabuse them of the wrong notions instilled into them.
\end{abstract}

Keywords: Michel Foucault; One Flew over the Cuckoos Nest; Paranoia.

\section{Introduction}

Paranoia, medically defined, refers to someone suffering from a mental illness that makes them believe other people are trying to harm them. It has, however, in recent years entered literary circulation. It, specifically elaborated, denotes an extreme and unreasonable feeling that others are going to damage you, and you do not feel safe. To put it succinctly, some trepidation and apprehension is always with you. Paranoia, writes Sim, is "the threat of total engulfment with somebody else's system," and is extremely felt by a large number of personas in postmodern fiction. It is speculated that this threat arises from the "climate of fear and suspicion" that was rampant and widely experienced by many over the course of the Cold War (1998: 129). It is an excruciating and traumatic 
experience many protagonists of postmodern fiction go through. They quite frequently suffer from it, from a "dread," according to Tanner, that another person is "patterning your life, that there are all sorts of invisible plots afoot to rob you of thought and action, that conditioning is ubiquitous" (as cited in Sim, 1998: 129)

What creates the atmosphere of trepidation and gets individuals into panic is most of the time engendered by authorities in a given society who, being afraid of the plausible menace on the part of mavericks, find them not malleable and therefore seek to erode their power and freedom by confining them for so long to, say, a prison, or in the case of Kesey's a mental hospital in which special treatments are undergone by individuals who seemingly need to be taken care of so as to make others immune to them. Mental asylum is a place to enclose the mad; because they are classified under the branch of 'unreason' in modern disciplinary societies; and "those who have lost the use of reason must be hidden from society" (Foucault, 1988: 227). A madman, it seems, is confined to an asylum to be cured, but the reality is that he is here "because he crosses the frontiers of bourgeois order of his own accord, and alienates himself outside the sacred limits of its ethics" (55). Madness is a form of social uselessness, and the mad should be separated from others. They are distinguished from others "by their inability to work and to follow the rhythms of collective life" (58). In his Discipline and Punish: The Birth of the Prison, Foucault argues against the idea that the prison became the consistent form of punishment due mainly to the humanitarian concerns of reformists. He traces the cultural shifts that led to the prison's dominance, focusing on the body and questions of power. Prison is a form used by the "disciplines", a new technological power. Whether it is a prison or a hospital, the main concern is to establish discipline (1995: 221). Foucault also notes that discipline creates "docile bodies", ideal for the new economics, politics and warfare of the modern industrial age. But, to construct docile bodies the disciplinary institutions must be able to ensure the internalization of the disciplinary individuality within the bodies being controlled. That is, discipline must come about without excessive force through careful observation, and molding of the bodies into the correct form through this observation (228). As it is portrayed in Kesey's novel, invisible forms of discipline oppressed individuals and their actions. Discipline here comes with excessive force: Maxwell Taber, a former patient stayed in Nurse Ratched's ward before McMurphy arrived. When Maxwell Taber questioned the nurse's authority, Ratched 
punished him with electroshock therapy. After the treatments made him completely docile, he was allowed to leave the hospital. He is considered a successful cure by the hospital staff.

In Madness and Insanity: History of Madness in the Classical Age, Foucault discussed how West European society had dealt with madness, arguing that it was a social construct distinct from illness. What Foucault says in the "Preface" is helpful in understanding Kesey's representation of the mental ward:

We have yet to write the history of that other form of madness, by which men, in an act of sovereign reason, confine their neighbors, and communicate and recognize each other through the merciless language of non-madness ... In the serene world of mental illness, modern man no longer communicates with the madman: ... the man of madness communicates with society only by the intermediary of an equally abstract reason which is order, physical and moral constraint, the anonymous pressure of the group, the requirements of conformity ( 1961: ix-x).

Having been fettered by an outside power, one becomes afflicted with a sense of disillusionment and it brings on an identity crisis which causes them to become estranged from the society in which they, like thousands of others, should have an inviolable right to be part of. Those in power but, by indoctrinating them to possess aberrant behavior that needs to be cured of it, seek to subjugate them in order to get them to be docile and tractable. This is the way a dominant bureaucracy in contemporary communities takes mavericks under their control to forestall possible disturbances, to vindicate their deeds, to perpetuate their supremacy, and ultimately to secure their dominance. This object is more often than not achieved by authorities in a given society. Paranoia, Fick suggests, "calls attention to the possibility of confinement, to one of the opposing terms which define a psychic frontier" (as cited in Bloom, 2007: 148).

Paranoid fiction is a term sometimes used to describe works of literature that explores the subjective nature of reality and how it can be manipulated by forces in power. Sometimes paranoid fiction will strongly imply, and occasionally admit outright, that its constructed world is a lie or an illusion. In this case, the plot will center on the main character's struggle between the physical and spiritual; i.e. the actual world they are in, versus the world they want to see and believe in. Here, the cause of the fantasy is the protagonist's internal desires, doubts, and suspicions. Such works tend to be more introspective and focused on the individual, than on a community or regime. These forces can be external, such as 
a totalitarian government, or they can be internal, such as a character's mental illness or refusal to accept the harshness of the world he is in.This definition is very consistent and applicable to Ken Kesey's novel.

Postmodern fiction represent "paranoid anxieties" in different ways, including; "the distrust of fixitiy, of being circumscribed to anyone particular place or identity," the belief that society is "conspiring against the individual," and the proliferation of "self-made plots to counter the scheming of others" (Sim, 1988: 131). Regardless of the nature of the anxiety engendered by authorities, the created paranoia brings on a type of unremitting apprehension and its concomitant phobia causing individuals to become recluse and introspective. Consequently, Paranoia, in Fick's words, "calls attention to the possibility of confinement, to one of the opposing terms which defines a psychic frontier" (as cited in Bloom, 2007: 148)

\section{Discussion}

One flew over the cuckoo's nest is narrated from the viewpoint of Bromden or as he is called by the black boys working in the hospital, Chief Broom, half Indian, a Columbia Indian, and by other patients Big Chief who has been in the ward longer than anyone else, and the one who pretends to be deaf and dumb, being kept in a mental hospital run by Miss Ratched, who is often referred to as the Big Nurse, a martinet, austere, and bossy person who, by issuing peremptory instructions, does not condone even the most minor infringements. Chief Bromden, the half-Indian narrator, has been a patient in an Oregon psychiatric hospital for ten years. He suffers from hallucinations and delusions and his paranoia is evident from the first lines of the book. Bromden's paranoia comes from his fear of what he calls the Combine, a huge conglomeration that controls society and forces people into conformity. Bromden's paranoia also is clear from his sense that he is not seeing things from an everyday perspective:

I been silent so long now it's gonna roar and of me like floodwaters and you think the guy telling this is ranting and raving my God: you think this is too horrible to have really happened. this is too awful to be the truth! But, please. It's still hard for me to have a clear mind thinking on it. But it's the truth even if it didn't happen (Kesey, 1962: 17).

Moreover, Bromden describes Nurse Ratched transforming into a huge machine, and he has to be sedated when the aides try to shave 
him and he starts screaming: "Air Raid". Up until this moment he has not addressed the reader directly: It is as though we are overhearing his private thoughts. The italicized words in the quote reveal that Bromden is requesting the reader to keep an open mind. His hallucinations provide an insight into the hidden realities of the hospital.

Bromden, who has been gaining self-awareness since McMurphy's arrival on the ward, remembers a scarring experience he had as a ten-year-old boy:

Except the sun, on these three strangers, is all or a sudden way the hell brighter than usual and I can see the ... seams where they're put together. And almost, see the apparatus inside them take the words I just said and try to fit the words in here and there, this place and that, when they find the words don't have any place ready-made where they'll fit, the machinery disposes of the words like they weren't even spoken. (213)

Three government officials came to speak to Bromden's father about buying the tribe's land and when Bromden tried to speak to them, he noticed that "not a one of the three acts like they heard a thing he said"(199). He begins to believe that he can see the seams on people, as though they were inhuman or machine-like. For Kesey, the ones who do the dirty work of an oppressive society are basically machines.

The novel constantly refers to different authorities that control individuals through subtle and coercive methods. The narrator, the Chief, combines these authorities in his mind, calling them "The Combine" in reference to the mechanistic way they manipulate and process individuals. The novel was written in 1959 and published in 1962 in the midst of the Civil Rights Movement.

Furthermore, the novel criticizes the emasculation of men in society, particularly in the character of Billy Bibbit, the stuttering acute who is domineered by both Nurse Ratched and his mother. Billy Bibbit is a shy patient. He has a bad stutter and seems much younger than his thirty-one years. Billy is dominated by his mother, one of Nurse Ratched's friends, Billy suffers from paranoia. He is voluntarily in the hospital, as he is afraid of the outside world. McMurphy arranges a date for Billy and bribes the night aide, Mr. Turkle to sneak Candy into the hospital. Billy has sex with Candy while McMurphy and the other patients smoke marijuana and drink. When the Nurse finds Billy with Candy, she threatens to tell his mother. Billy becomes paranoid and commits suicide. 
With the exception of the prostitutes, who are portrayed as good, the women in One Flew Over the Cuckoo's Nest are uniformly threatening and terrifying figures who contributed to the characters' paranoia. Bromden and McMurphy tend to describe the suffering of the mental patients as a matter of emasculation or castration at the hands of Nurse Ratched and the hospital supervisor, who is also a woman. These acts result in causing paranoia in the characters of the patients.

It is the story of Bromden's own journey toward sanity. When the novel begins, Bromden is paranoid, bullied, and surrounded much of the time by a hallucinated fog that represents both his medicated state and his desire to hide from reality. The critique of the mental ward as an instrument of oppression comparable to the prison mirrored many of the views that Michel Foucault was making at the same time.

Nurse Ratched representsoppressive mechanization, dehumanization and emasculation of modern society - in Bromden's words, the Combine. Bromden describes her being like a machine. Her ability to present a false self suggests that the mechanistic and oppressive forces in society gain ascendance through dishonesty of the powerful.

Again Foucault remarks that discipline creates "docile bodies" in the modern industrial age. Without being aware of the oppression, the quiet and docile slowly become weakened and gradually subsumed (1995: 211). Nurse Ratched maintains her power by the strategic use of shame and guilt, as well as by a determination to "divide and conquer" her patients. McMurphy represents sexuality, freedom, and self-determination; characteristics that clash with the oppressed ward, which is controlled by Nurse Ratched. He is not crazy, but rather he is trying to manipulate the system to his advantage. Maxwell Taber, a former patient who was, according to Ratched, a manipulator, is subjected to electroshock treatments and ends up a helpless vegetable and is left docile and unable to think.

In Madness and Insanity: History of Madness in the Classical Age, Foucault discussed how West European society had dealt with madness, arguing that it was a social construct distinct from mental illness. What Foucault says in the "Preface" is helpful in understanding Kesey's representation of the mental ward:

we have yet to write the history of that other form of madness, by which men, in an act of sovereign reason, confine their neighbors, and communicate and recognize each other through the merciless language of non-madness ... In the serene world of mental illness, 
modern man no longer communicates with the madman: ... the man of madness communicates with society only by the intermediary of an equally abstract reason which is order, physical and moral constraint, the anonymous pressure of the group, the requirements of conformity. (1961:210)

It is just this sense of alienation and confinement that Kesey explores through the eyes of his first-person narrator, Chief Bromden, his emories of madness are reported with all the distortions of reality that accompanied his original perception of those events.

Here Bromden, along with some other patients, often receive shock treatments. The mental asylum portrayed in the novel is like a prison as we can see Miss Ratched unlocks its main door when she wants to comes into it every morning; and the windows of the asylum are covered with hard screens of mesh which may not be broken by knocking them with a chair or a bed. The inmates are entrapped in a prison-like asylum, and there is no way out. This imprisonment, Foucault asserts, "covered both the deprivation of liberty and technical transformation of individuals" (1995: 233). This deprivation of liberty means that the inmates' time is completely under the control of the disciplinary authorities. Chief Bromden states that "the Big Nurse is able to set the wall clock at whatever speed she wants." (Kesey, 1962: 76)

The asylum does not enclose only the madmen who "depart from reason with confidence" or, in Sauvages words, "those who are actually deprived of reason or who persist in some notable error" (as cited in Foucault, 1988: 104). It also consists of other forms of social uselessness. There are many inmates depicted in the novel who are not mad but socially useless; Sefelt and Fredrickson are epileptics; Chief Bromden is a homeless Indian who is deaf and mute (although he feigns to be deaf and mute); Harding is accused by his wife of being a homosexual; Billy Bibbit has childish behavior according to his mother; and many of the Chronics called Vegetables, have vegetation life. Almost all the inmates of the asylum have some inabilities; they cannot perform the duties which have been imposed on them by society; many of them may explode occasionally into such outbursts that are regarded as a type of social danger. In short, they cannot assimilate themselves to the norms of bourgeois society; therefore society excludes and confines them, and this confinement, as Foucault maintains, is explained, or at least justified, by the desire to avoid scandal" (1988: 66). 
The abnormal are distinguished from the normal in some respects so that they can easily be recognized; they deviated from the norms which are respected by the normal and this makes them different. The court rules McMurphy is a psychopath, because he is "got in a couple of hassles at the work farm" (Kesey, 1962: 13) while he is there to work. A madman, better say an abnormal, is recognized by majority of people who look at him. "Madness is immediately perceived as difference: whence the forms of spontaneous and collective judgment sought, not from physicians, but from men of good sense" (Foucault, 1988: 116). All the men of good sense can recognize this difference and are aware of this abnormality; therefore it is the majority of the public that marginalize the minority, those who are different. In the way to sea-port Chief Bromden mentions the people "who were driving past on their way to work slow down to gawk at all the loonies in green uniforms" (Kesey, 1962: 234) and those on the docks who were mocking and ridiculing them. Harding explains the public view on their abnormality when he answers McMurphy's question about the damage which shock therapy has on patients and explains the reasons why the public does not raise Cain about it. At the end he says that "in this country, when something is out of order, then the quickest way to get it fixed is the best way" (190).

Sometimes society makes something becomes different, something which is not really different but may only seem strange, such as Chief Bromden, the tall robust Indian, who has been silenced whenever he wanted to speak since he was a child. He was not the one who decided to adopt being deaf and mute, but it was the others who treated him as if he was deaf and mute. He says that "it wasn't me that started acting deaf; it was people that first started acting like I was too dumb to hear or see or say anything at all" (210). He pretends to be deaf and mute in the asylum, because the staff in the asylum ignores him, too. The repetition of this attitude towards the mad by the public makes them believe in their abnormality as their guilt. It is this guilt that the asylum organizes "for the madmen as a consciousness of himself, and as a nonreciprocal relation to the keeper" (Foucault, 1998: 247). Billy Bibbit, the stuttering young inmate, speaks rather depressively about himself and other inmates who admit their guilt and believe in their abnormality:

You think I wuh-wuh-wuh-want to stay in here? You think I wouldn't like a con-con-vertible and a guh-guh-girl friend? But did you ever have people 1-1-laughing at you? No, because you're so b-big and so 
tough! Well, I'm not big and tough. Neither is Harding. Neither is F-Fredrickson. Neither is Suh-Sefelt. Oh-oh, you-you t-talk like we stayed in here because we liked it! (Kesey, 1962: 195)

Upon the arrival of a new patient named Randle Patrick McMurphy conditions, however, appear to be less severe and more pleasing. McMurphy is transferred there for diagnosis and possible treatment due to rape with a girl. In this hospital those being kept fall into two categories: Acutes and Chronics who are not permitted to mingle. Acutes are called so because "doctors figure them still sick enough to be fixed" (15) and Chronics are "machines with flaws inside that cannot be repaired" (16), and any objection to the way the system operates will cause the patients to be "listed as Potential Assaultive and shipped upstairs to the Disturbed ward" (69). Bromden, it is said, underwent more than two hundred "shock treatments" that led up to his being a "sweeping machine, scared of its own shadow" (69).

McMurphy, "the new redheaded admission", and the one who, as the big Bromden thinks of him, is "no ordinary admission" from the time he enters the hospital, has complete contempt for both Miss Ratched and other staff, asserts he has entered there to bring the psychopaths fun and entertainment, and is aware of the fact that he is not a Chronic. What The Big Nurse aspires to obtain here is a "world of precision efficiency and tidiness like a pocket watch with a glass back, a place where the schedule is unbreakable" (29). McMurphy is but, as doctors conclude, a "disturbing factor" that must be swiftly gotten rid of so as to restore order now that chaos is ascendant. They intend to surmount any obstacle to achieve their goals and McMurphy is a threat to them. He frustrates their efforts. Jettisoning him is thus obligatory and exigent. Since they find him intractable and refractory, some propose it would be prudent to "send him up to Disturbed" (155). The Big Nurse but holds a difference of opinion. By doing so, she thinks, "he would be a martyr to them" (157) and would be thought of as an extraordinary man that they had been unable to handle and thus had shirked their responsibilities. McMurphy, the Big Nurse believes, is a man like others with fears and mistakes, and by keeping him in the ward "his self-made rebellion will dwindle to nothing" (157).

In the meeting titled "Therapeutic Community" patients and doctors congregate where the psychos are instructed how to behave with proper decorum, how to avoid appearing gauche, and how to adapt themselves 
with their milieu. Those presiding over the hospital, the Big Nurse contends, aim to make there a democratic community corresponding roughly to the outside world with which the psychopaths have lost contact, but need to be sanguine about the prospect of, according to her, taking their place in again someday. The meeting, McMurphy thinks, is but "a bunch of chickens at a peckin' party" (57). The way the meeting and its object is rationalized is worth considering, "the goal of therapeutic community is a democratic ward, run completely by the patients and their votes, working toward making worthwhile citizens to turn back outside onto the street" (49). The psychos dwelling in here will have to face the consequences if they remonstrate against the ascendant system and its mechanism. Pete, being "a Chronic all his life," for instance, when for once he objects to, and rails at, the Therapeutic Community and the manner the patients are goaded into confessing to their nefarious activities perpetrated in the past, only by calling out he is "tired" is given a shot and is treated so harshly that he "never tried anything like that again, and he never will" (55).

The patients are here indoctrinated to believe they suffer mental problems and need to be taught how to handle other people, and the Big Nurse and the doctors have been highly successful in achieving their goals, in fixing false notions in their minds. McMurphy is the only person who frustrates, at least momentary, the authorities' plans. He uses his overt sexuality to throw Rathced's off her machinelike track, and he is not taken by her thin façade of compassion or her falsely therapeutic tactics. When McMurphy rips her shirt open at the end of the novel, he symbolically exposes her hypocrisy and deceit, and she is never able to regain power. Not only McMurphy is a rebel but also Charles Cheswick, the first patient to support McMurphy's rebellion against Nurse Ratched's power.

McMurphy, as he himself asserts, has observed thousands who by exploiting individuals' weakness and ignorance seek to subjugate them in an insidious manner and get them to "toe the line, to follow their rules, to live like they want you to" (60). The psychos have, nonetheless, become inured to the dire situation from which they are not keen on extricating themselves from, and think of the Big Nurse as "sweet, smiling, tender angel of mercy" (60), being "unselfish as the wind, toiling thanklessly for the good of all" (61) and a benevolent woman who "serves mankind on her weekends off by doing generous volunteer work about town" (61). This is patently obvious in the conversation between McMurphy and 
Harding, president of the Patient's Council who admits that he was born a "rabbit" and the one who, he believes, needs someone like the Big Nurse to make him happy with his role, when McMurphy struggles to disabuse him of his wrong ideas, but Harding adheres strictly to them:

This world...belongs to the strong, my friend! The ritual of our existence is based on the strong getting stronger by devouring the weak. We must face up to this. No more than right that it should be this way. We must learn to accept it as a law of the natural world. The rabbits accept their role in the ritual and recognize the wolf as the strong. In defense, the rabbit becomes sly and frightened and elusive and he digs holes and hides when the wolf is about. And he endures, he goes on. He knows his place. He most certainly doesn't challenge the wolf to combat. Now, would that be wise? Would it? (64)

The irony of the situation is that some patients or as they referred to, Acutes, as a result of the blunders the staff made, were transformed to Chronics. Ellis was, upon his arrival, one of Acutes who, because of the treatments he received in "that filthy brain-murdering room that the black boys call the shock shop" (16) was changed into a Chronic for example. Or in the case of Ruckly who used to be a nuisance to both the black boys and the nurses, after having been taken away to be fixed, abjured his misbehavior and turned to a docile one. Sometimes one going over to that room for an installation "leaves the ward mean and mad snapping at the whole world" (170) and within a few weeks gets back being the "sweetest, nicest, best-behaved thing you ever saw" (17). This metamorphosis is, the employees conclude, a success, but just another robot for the Combine, Bromden believes.

One of McMurphy's efforts to ameliorate and alleviate the patients' appalling situation is inducing them to take a vote on watching baseball games to demonstrate they still got some guts, to show they have the audacity to flout the authorities, to prove themselves after growing effete due to the presence of a formidable power. Though his first attempt does not pay off, he remains tenacious and does not waver in his effort to get authorities to enfranchise them till he ultimately triumphs. He tries to bolster the apparently patients' confidence and morale and does not begrudge doing anything to obtain his purpose. Once he asserts he is capable of lifting the control panel and send it throw the window, but he does not succeed. Despite this he says, "But I tried, though, Goddammit, I sure as hell did that much, now, didn't I?” (125). 
The rules and limitations imposed on the patients are completely vindicated on the grounds that they are to the benefit of them, and the kind of therapy they receive is conducive to good health. A salutary experience, to put it this way, which is ineluctable if they intend to shape up. The way the Big Nurse puts it is worth noticing:

Please understand: we do not impose certain rules and restrictions on you without a great deal of thought about their therapeutic value. A good many of you are in here because you could not adjust to the rules of society in the Outside World, because you refused to face up to them, because you tried to circumvent them and avoid them. At some time-perhaps in your childhood-you may have been allowed to with flouting the rules of society. When you broke a rule you knew it. You wanted to be dealt with, needed it, but the punishment did not come. That foolish lenience on the part of your parents may have been the germ that grew into your present illness. I tell you this hoping you will understand that it is entirely for your on good that we enforce discipline and order. (199-200)

McMurphy is the only person who, from the very outset he is committed to the hospital, is cognizant of the fact that he is not insane and suspects that he is, to quote Sim, "trapped at the center of an intrigue, often with some justification." (130). He also tries to remind others that they are laboring under the illusion that they are insane. Contrary to popular opinion, and even to their own belief, they are sane and need not being confined there. Again during a conversation with Harding, McMurphy does his best to get him to obliterate the wrong idea from his mind: "you ain't crazy that way. I mean-hell, I been surprised how sane you guys all are. As near as I can tell you're not any crazier than the average asshole on the street" (65).

It is an axiomatic fact that every individual needs at least a brief relief from harsh realities of life, and the fishing expedition arranged by McMurphy is a welcome respite from the pressures of the monolithic hospital. Once again, he, being aware of the patients' excruciating condition and their incapability to laugh, essays to exhort them to be jubilant and elated even in the face of being embroiled in a situation from which it appears to be implausible to escape:

While McMurphy laughs. Rocking farther and farther backward against the cabin top, spreading his laugh out across the water-laughing at the girl, the guys...because he knows you have to laugh at the things 
that hurt you just to keep yourself in balance, just to keep the world from running you plumb crazy. (249-50)

Despite McMurphy's sustained efforts, however, due to the shock therapies in general, and lobotomy in particular, he is transformed from a man of power into an effete person exerting no influence within the hospital any longer. Nonetheless, being highly influenced by McMurphy who made him grow, Chief Bromden who cannot tolerate this situation, smothers him with a pillow, lifts the control panel and absconds the hospital. McMurphy is hailed a "messiah" who showed Chief Bromden and others the "way home." Bromden repeatedly "creates his own womb when he withdraws into his fog," but ultimately manages to disentangle himself from his current situation and becomes "purified by the love of his messiah" (Bloom, 2007: 81). Not only does he comes under the influence of McMurphy, but also the other men, having been observed his unremitting attempt to boost their ego, learn to wrest control of their lives, to challenge the authorities.

The imprisoning of McMurphy by "outside powers" engenders a "panic of identity." He faces an identity crisis, and thus he struggles to demonstrate his sanity. This demur, however, that he is sane is itself deemed by authorities an indication of his insanity (Sim, 1988: 131). McMurphy's harrowing condition exemplifies those who are recognized as unorthodox thinkers and are not inclined to conform to and obey the ruling standards of behavior. He is conscious of, and simultaneously contemptuous of, the hospital's bureaucracy and exhorts others to flout the existing code of conduct which has caused them for long to be both physically and emotionally abused.

\section{Conclusion}

As discussed, Kesey in the above-examined work, portrays a monolithic mental hospital in which its bureaucracy, by imposing strict instructions, subject the seemingly psychopaths to inequitable treatments and seek to instill a sense of insanity into them. This situation gradually creates an illusion that they suffer from an ailment and need to be taken care of, resulting in a perennial trepidation and paranoia, ultimately causing sufferers to become estranged from society and be thought of as social outcasts, ones who must not be made contact with by apparently sane people. This is the way officials in contemporary communities forestall 
the prospect of any menace on part of iconoclasts who, if they do not be suppressed, have the capability to subvert a ruling system whose perpetuation ensues from exploiting people's ignorance. Kesey's indeed perfectly exemplifies the sort of treatment undergone by those suffering from mental illness and the way they are mistreated.

\section{References}

Bloom, Harold. (2007). Ken Kesey's One Flew over the Cuckoo's Nest. New York: Bloom's Literary Criticism.

Foucault, Michel. (1995). Discipline and Punish: the Birth of the Prison. Alan Sheridan, trans. New York: Vintage Books.

. (1988). Madness and Civilization: A History of Insanity in the Age of Reason. Richard Howard, trans. New York: Vintage books

. (1961). Madness and Insanity: History of Madness in the Classical Age. Routledge.

Kesey, Ken. (1962). One Flew Over the Cuckoo's Nest. New York: Penguin Group.

Leach. Caroline. (2008). "Disability and Gender in Ken Kesey's One Flew Over the Cuckoo's Nest." Disability Studies Quarterly (Fall) Volume 28, No. 4, www.dsq-sds.org

Rich, Nathaniel (2012). Ken Kesey's Wars: “One Flew Over the Cuckoo's Nest" at 50. http://www.thedailybeast.com/articles

Rich, Nathaniel. (2012). Ken Kesey's Wars: “One Flew Over the Cuckoo's Nest" at 50. http://www.thedailybeast.com/articles

Sim, Stuart. (1998). The Routledge Companion to Postmodernism. London \& New York: Routlege. 